DOI: https://doi.org/10.18524/2519-2523.2021.16.245738

УДК 94(477) «Чайковський»

\title{
THE FINAL SECRET OF MYKHAYLO CZAJKOWSKI: cause of death of a prominent Ukrainian politician
}

\section{Volodymyr Poltorak}

Ph.D (History), Associate Professor Odesa I. I. Mechnikov National University 2, Dvoryanska Str., Odesa, 65082, Ukraine

ORCID: https://orcid.org/0000 0003 04066907

E-mail: poltorak@onu.edu.ua

Citation: Poltorak, V. (2021) The final secret of Mykhaylo Czajkowski: cause of death of a prominent Ukrainian politician. Chornomors'ka mynuvshyna, vol. 16 , pp. $51-56$.

Submitted: 14.11 .2021

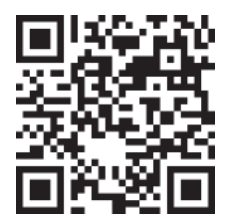

\section{Annotation}

The political and literary activity of Mykhailo Czajkowski (Sadyk Pasha) was full of many riddles and taunts. The last updates and publications of documents shed light on most of them. The circumstances of the death of a prominent Ukrainian politician still unclear, as there are too many myths and rumors about what actually happened on the night of January 5 (January 17 in the new style) in the Czajkowski estate in Chernigov gubernia. Based on the new data found, in particular - on the metric records of the deaths of Adam Morozovych and Mykhailo Czajkowski, this article rejects outright nonsense and falsifications, which immediately after the death of General reached the press, and from there - to public opinion. The question of the probability of the version of the suicide of a retired Turkish General and a man who first created the concept of the Ukrainian state in the nineteenth century, author is answered negatively.

Key words: Mehmed Sadyk Pasha (Mykhaylo Czajkowski), suicide, murder, falsification of evidences.

\section{ОСТАННЯ ТАЕМНИЦЯ МИХАЙЛА ЧАЙКОВСЬКОГО: причина смерті видатного українського політичного діяча}

\section{Володимир Полторак}

Кандидат історичних наук, доцент

Одеський національний університет імені I. I. Мечникова Вул. Дворянська, 2, м. Одеса, 65082, Україна

ORCID: https://orcid.org/0000 0003 04066907

E-mail: poltorak@onu.edu.ua

Цитування: Полторак В. Остання таємниця Михайла Чайковського: причина смерті видатного українського політичного діяча. Чорноморська минувшина: записки Відділу історії козацтва на півдні України: зб. наук. пр. / за. ред. В.А. Смолія. Одеса: ФОП Бондаренко М.О., 2021. Вип. 16. С. 51-56.

Отримано: 14.11.2021 p.

\section{Анотація}

Активна політична та літературна діяльність Михайла Чайковського (Садик-паші) залишила після себе багато загадок $і$ таємниць. Останні дослідження та публікації документів проливають світло на більшість із них. Нез'ясованим залишається ще питання обставин смерті видатного украӥнського політичного діяча, адже аж надто багато міфів та чуток виявляється навколо того, щуо насправді сталось в ніч на 5 січня (17 січня за новим стилем) 1886 року в маєтку Чайковських. На основі віднайдених нових даних, зокрема - на метричних записах про смерть Адама Морозовича та Михайла Чайковського в иій статті відкинуті відверті нісенітниці та фальсифікати, які одразу після смерті Михайла Чайковського потрапили до преси, а звідти - до громадської думки. На питання про вірогідність версії про самогубство відставного турецького генерала та людини, яка вперше створила конщепцію Української держави у XIX ст., дається негативна відповідь.

Ключові слова: Мехмед Садик-паша (Михайло Чайковський), самогубство, вбивство, фальсифікація свідчень та доказів. 
Активна політична та літературна діяльність Михайла Чайковського (Садик-паші) залишила після себе багато загадок і таємниць. Останні дослідження та публікації документів проливають світло на більшість із них. Нез'ясованим залишається ще питання обставин смерті видатного українського політичного діяча, адже аж надто багато міфів та чуток виявляється навколо того, що насправді сталось в ніч на 5 січня (17 січня за новим стилем) 1886 р. в маєтку Чайковських. На основі віднайдених нових даних, зокрема - на метричних записах про смерть Адама Морозовича та Михайла Чайковського в цій статті ми спробуємо відкинути відверті нісенітниці та фальсифікати, які одразу після смерті Михайла Чайковського потрапили до преси, а звідти - до громадської думки. Якщо коротко, то головне питання - наскільки вірогідною є версія про самогубство відставного турецького генерала та людини, яка вперше створила концепцію Української держави у XIX ст.?

В листі своєму товаришеві по зброї Томашу Вербицькому (Мурад-бею) у 1878 р. відставний турецький генерал Мехмед Садик-паша написав: “Дивна історія випадків - на иіій землі між Остром і Десною, - Розумовський з пастуха індиків став гетьманом Украӥни, а Чайковський з командувача козаками перелицювався на пастуха індиків. Пасу індиків, поки не піду в небіжчики" [1, s. 532].

Останні десятиліття Чайковського були завершенням його життєвої “Одісеї” - він повернувся до своєї омріяної козацької України. Карколомний як для його сучасників оберт долі - польський повстанець, турецький генерал скористався запрошенням російського імператора і повернув до України.

Але що то був за час? Покровителька козацтва в Туреччині, Франція розгромлена Другим Рейхом і шукає союзників проти Німеччини. Австрія стала Австро-Угорщиною. Османська імперія під загрозою слов'янського повстанського руху (четників) та через радикалізацію думок ісламської політичної еліти відступила від ліберальної моделі модернізації. Польський визвольний рух став на шлях еволюційний. Імперія Російська переживала небачені реформи - селяни звільнені, призовна армія, рівність усіх перед судом, автономія університетів, обмеження цензури, земства... У вільнодумців першої половини XIX ст. голова йшла обертом від можливостей. А у відставного турецького генерала пробудилась туга за батьківщиною. До того ж посольство Російської імперії в Константинополі доклало максимум зусиль для організації повернення Садик-паші, зацікавлене в його медійній популярності для зміни образу імперської влади серед поляків. Здається, що французькі знайомі Чайковського також усіляко були зацікавлені в цьому, очікуючи на можливий союз з Російською імперією. Тож нічого дивного і непередбаченого в рішенні відставного козацького генерала не було.

Перші роки жив в Києві. На пенсію від султана, гонорари від друку книжок та подарунки від Олександра II. Спробував стати агентом впливу на польську громаду - але був холодно проігнорований. Заходився писати спогади - пережив наново усе своє життя. Активно листувався 3 ветеранами османського козацтва. Придбав маєток в Чернігівській губернії і перебрався туди. За повідомленнями, його володіння склали трохи більша ста десятин, i звичайно вони не могли дати достатнього для його родини прибутку. Тому до останнього подиху він продовжував робити те, що йому вдавалось краще за все в житті - створювати нові ідеї та тексти.

Ще в Стамбулі він втретє (за деякими даними - вчетверте) одружився на Ірені з роду Теосколо (в деяких працях її помилково називають Терезою). За свідченнями, грецька красуня спочатку була викрадена у першого чоловіка молодшим сином Михайла - Владиславом (Музафером). Потім той покинув іiі, і молода особа звернулась до Садик-паші за допомогою. гречний паша оселив невістку при собі, а потім одружився на ній, рятуючи честь сім'ї. У Стамбулі генерала вже майже нічого не тримало - 3 армії пішов у відставку, старший син Адам вступив до російського війська - і вже після смерті батька дослужився до чину генералмайора. Одне з останніх повідомлень про старшого сина - звіт Сімферопольського ВЧК про конфіскацію в 1919 р. у генерал-майора у відставці Чайковського фамільної шаблі, яка належала гетьману I. Брюховецькому [7, с. 59-69] та відзначення в переліку померлих в 
лазареті у Сімферополі у 1920 р.: “3 марта отставной генерал-майор Адам Михайлович Чайковский, 80 лет от роду, от общего старческого склероза" [6, арк. 21].

8 вересня 1873 р. вже в Києві Михайло Чайковський знову став батьком - Ірена подарувала йому доньку Олександру (іноді її в джерелах називають Ольгою). Дата народження виключає батьківство Владислава (Музафер-паши) і залишає поза сумнівом батьківство Мехмеда Садик-паші. Молодший син Владислав, залишившись при дворі султана, зробив непогану кар'єру - вершиною iï стало управління Ліваном у 1900-1907 pp. [8, с. 103-112]. Дві доньки лишились спочатку на Балканах, згодом Кароліна перебралась до Трієсту, де й померла у 1901 р. Третя, найменша донька Олександра отримувала освіту в Патріотичному жіночому інституті в Києві, а після смерті батька - у Санкт-Петербурзі (закінчила Смольний у 1891 р.).

Тим часом генеральська старість у пасторальних сіверських пейзажах наближала Чайковського до неминучого завершення його життя...

Навесні 2011 р. з Оленою Бачинською та Олександром Кухаруком ми помандрували до Бірок - села, в якому зберігся до того часу маєток Садик-паші - Чайковського. Дорога 3 Чернігова до Козельця, а далі битим шляхом до Остра. В Бірках край села - дерев'яна будівля. Колишня школа і панський будинок. Двері відчинені для візитерів. Занедбані зали, розбиті вікна, розкидані старі підручники, розібрані груби... Тут в ніч 34 на 5 січня 1886 p. Чайковський був смертельно поранений в груди. Куля потрапила в брюшину, серце залишилось неушкодженим...

Польський історик Францішек Равіта-Гавронський докладно змалював останні години Садик-паші в цьому самому будинку, проте подальші недоречності його версії настільки очевидні, що іiі скоріше слід розглядати як творчу адаптацію подій. Отже, на думку Францішека, на Різдво до батьків прибула з Петербургу донька, що за документами вже неможливо, бо за статутом шляхетних інститутів дівчата не залишали стін навчального закладу взимку, та й вчилась тоді Олександра в Києві, а не в Петербурзі. На ранок, за словами Равіти-Гавронського, мати повинна була везти доньку до залізничної станції на потяг. Михайло вимагав, аби Ірена взяла з собою слугу, дружина відмовлялась. Молодша на сорок років від чоловіка, вона мала коханця (якогось поляка Янковського) - і підстаркуватий Чайковський неодноразово сварився 3 нею через це. Начебто шантажуючи дружину самогубством, Михайло пішов до своєї спальні. Усю ніч щось писав, а над ранок 3 п’ятизарядним револьвером рішуче увійшов до спальні дружини, де також ніби ночувала й донька, сів на край ліжка й вистрелив собі у груди. До кімнати на звук пострілу увійшов російський офіцер, що ночував в одній із кімнат, і переніс вмираючого Садик-пашу до його кімнати. Поки покликали лікаря, Михайло стік кров'ю. Останні слова, що начебто промовив, були “Життя набридло” [3, s. 98]. Картина, змальована Равітою-Гавронським дуже докладна, проте суперечлива, і скоріш за все вигадана талановитим істориком.

Інший варіант смерті змальований лікарем Клодницьким, дійсно присутнім при смерті Михайла. Останні роки Чайковського лікар мав тісні контакти з ним і був свідком слідів побиття старого генерала молодою і запальною дружиною, яка до того ж “скакнула в гречку” 3 прикажчиком Янковським. Його (прикажчика) погрози теж тримали Чайковського у стані очікування вбивства, про що він повідомляв Клодницькому [2]. Версія 3 підготованим чи випадковим вбивством Михайла підтверджують й інші невідповідності у версії, які переповідав Равіта-Гавронський зі слів скоріш за все Ірени, зацікавленої у смерті свого чоловіка. По перше - як могло статись, що військовий, який нібито готував самогубство, не зміг застрелитись і поцілив собі у правий бік. По друге, Чайковський за всіма повідомленнями щось писав перед смертю - проте папери не були віднайдені. Якщо він готувався до самогубства - то в листах мав би це підтвердити, але папери зникли. По третє, донька Олександра не могла бути на канікули в Бірках, бо на той момент навчалась в Інституті, розпорядок якого не передбачав таких канікул. Отже, алібі Ірени Теосколо-Чайковської не витримує навіть поверхової перевірки.

Підхоплена польською та російською пресою версія про самогубство швидко оволоділа суспільною свідомістю, для якої екстравагантний відставний генерал 3 його постійною 
особливою позицією і на той світ мав відійти не як усі. Навіть з'явилась чутка, що це сам Михайло Чайковський повідомив заздалегідь “Варшавський вісник” про своє самогубство [10, c. 188], що начебто підтверджувало його готовність накласти на себе руки.

Питання загибелі генерала Чайковського мала розглядати комісія зі станового пристава та лікаря (того самого Клодницького, який залишив спогади про події 1886 р.). От що нам оповідає метричний запис про загибель Михайла: “Счет умерших: мужеска полу 1. Месяи и день: смерти Генваря 5. Месяч и день: погребения Генваря 9. Звание, имя, отчество и фамилия умершего: Отставной генерал Михаил Станиславович Чайковский. (Подписи:) Священник Василий Светов Псаломщик Иван Воронькевич. Лета умершего: 82. От чего умер: от выстрела из револьвера. Кто исповедовал и приобщал: Священник села Бирок Иоанн Котляров. Кто совершал погребение и где погребены: По отношению Г. Пристава 2-го стана Остерского уезда от 8 января 1886 за №175м Свящзенник Василий Светов с псаломщиком Иваном Воронькевичем провел до могильл с пением Святый Боже” [4, арк. 276]. Як бачимо в офіційному записі про смерть не йдеться (!) про самогубство. Більш того, відзначено, що Чайковський був православним (сповідався та причащався у священника села Бірок) і був відспіваний. Впадає у вічі затримка поховання - воно відбулось на 5-й день після загибелі.

Отже, пан-отець із сусіднього до Пархимова села Котово Василь Свєтов 3 псаломщиком Іваном Воронькевичем віддали небіжчика землі [5, арк. 276]. Іван-Кристо Стойчев 3 невідомого джерела, близького до родини Михайла Чайковського, додав ще подробиці поховання: «Послідовник Мухаммеда, який навернувся у православ'я, вісімдесятирічний самогубець поклав на груди перед смертю ікону Святої Богородиці Ченстоховської (католицької святині), з якою ніколи не розставався» [10, с. 188]. Равіта-Гавронський, посилаючись на своїх інформаторів, але до певної міри фантазуючи, зазначає: “Солдати (арханелогородського полку) зайнялись його похованням: зробили труну і поклали в неї тіло; поховання затрималось через очікування дозволу від властей. Виникло питання: де його ховати $і$ як, адже був самогубець і мусульманин. Перед смертю не сповідався $i$ жодного бажання про поховання не оголосив (!). Доля не лише трагічно позбавила його життя, але й по смерті знак трагізму на ньому поставила. Тіло його перенесено було до шпихліру (амбару), а оскільки труна в двері не проходила, то довелось тіло з неї вийняти, труну боком внесли, а потім знову тіло в труну покласти. Все ие виконали солдати. Але й на изому трагізм його долі не закінчився. Вмираючи, бажав собі бути похованим поруч Морозовича. Треба його було перевези до Пархимова. Отож очікували на дозвіл. Надійшло врешті рішення поховати його по обряду християнському. Оскільки то була зима, покладено труну на прості селянські сани, гринджоли, запрягли пару коней $i$ відвезли до Пархимова. I тут тільки солдати архенелогородиі віддали йому посмертну шану. Перед Пархимовом жалобну ходу зустрів місцевий священник з хоругвами, $і$ не на цвинтарі, а на звичайному городі, поруч могили Морозовича, окропивши його святою водою, поховали" [3, s. 96]. Цю версію польського історика, окрім суперечливості питання про останню волю небіжчика, розвінчує ще один метричний запис.

За рік до смерті Чайковського помер його ад’ютант Адам Морозович. Ось про що йдеться в записі про його поховання в Пархимові: “Смерть: Генваря 12; Погребение: Генваря 14. Дворянин проживавший в селе Пархимове Адам Карлович Морозович. 57 лет. От удара. Римско-Католического исповедания. По отношению пристава 2 стана Остерского уезда от 13 января за №97 провожен с пением Святый Боже священник Василий Светов, с испр. псаломщиком Иваном Воронькевичем на кладбище”" [5, арк. 324 зв. - 325]. Що впадає у вічі? Не такий вже й підстаркуватий вік Адама (його усі історики змальовують чи не ровісником Михайла). I головне - розвінчуються міфи про місце поховання Морозовича - чітко відзначено, що він похований на цвинтарі, а не «на городі», як про це зазначає Францішек Равіта-Гавронський.

Подальші пошуки в архівах Київської та Чернігівської областей на жаль не дали можливості 3'ясувати подробиці розгляду смерті Чайковського становим приставом (матеріалів пристава 2-го стану Остерського повіту за 1886 р. не збереглись). Тому достеменно 
з'ясувати останню таємницю Михайла Чайковського наразі неможливо. Можемо наче детективи розглядати різні версії, звертати увагу на зацікавленість у смерті його дружини та іiі коханця, шукати алібі, в творах небіжчика не віднаходити суіцидальних мотивів. Проте усі ці інтелектуальні пошуки не можуть отримати остаточного вирішення без нових документів. Достеменно зрозуміло, що повної впевненості у самогубстві Михайла наразі немає.

Український історик Натан Рибак промовисто характеризує поховання нашого героя: “Хоч похорони Чайковського були величаві, за його домовиною не йшов ні один поляк” [9, c. 86-97]. Так закінчилось бурхливе життя Михайла Чайковського. Вже в наш час на могилі було встановлено монумент, а на батьківщині у селі Гальчині планують створити музей в родовому маєтку Чайковських. Під пером істориків та письменників він знов оживає, знов любить, знов будує козацьку Україну і на чолі своїх козаків вступає до Києва...

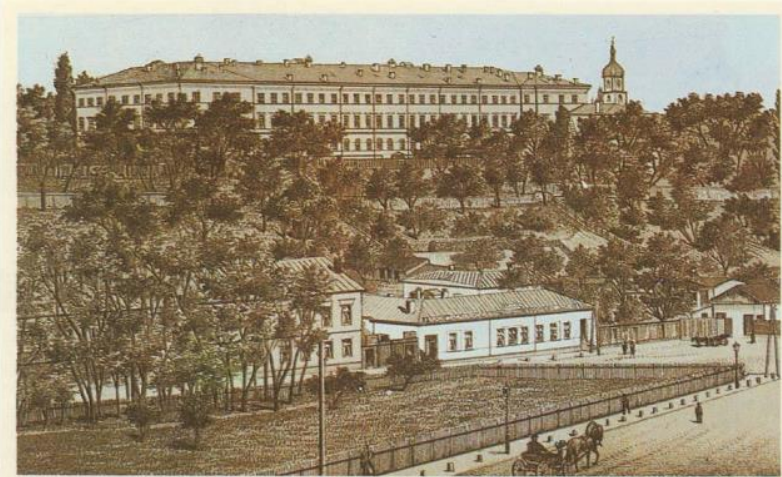

Шляхетний інститут в Києві, де навчалась донька Михайла Чайковського Ольга (Олександра)

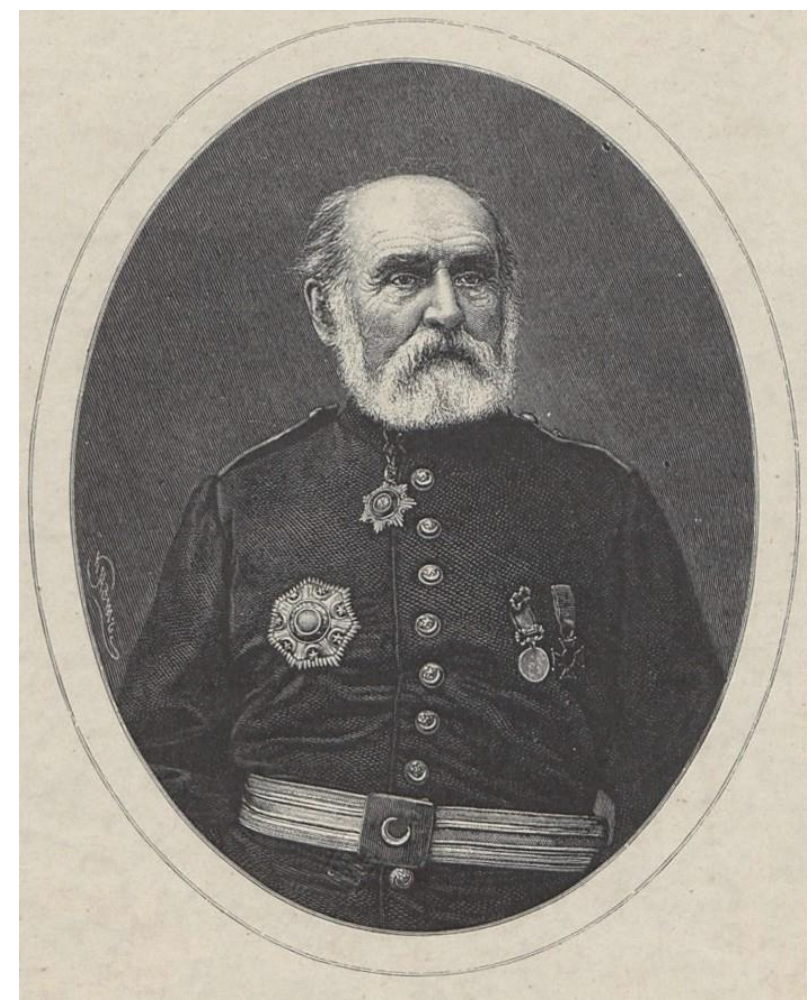

Михайло Чайковський в середині 1870-х рр.

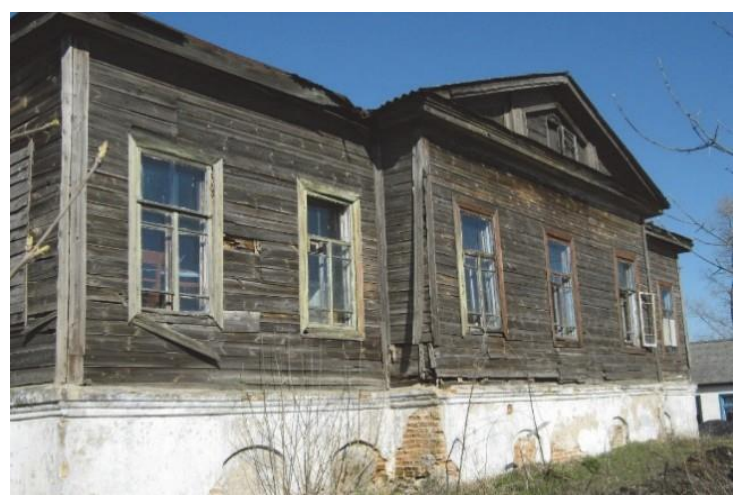

Маєток Чайковський в Бірках, де Михайло помер 5 січня 1886 р. (фото 2011 р.)

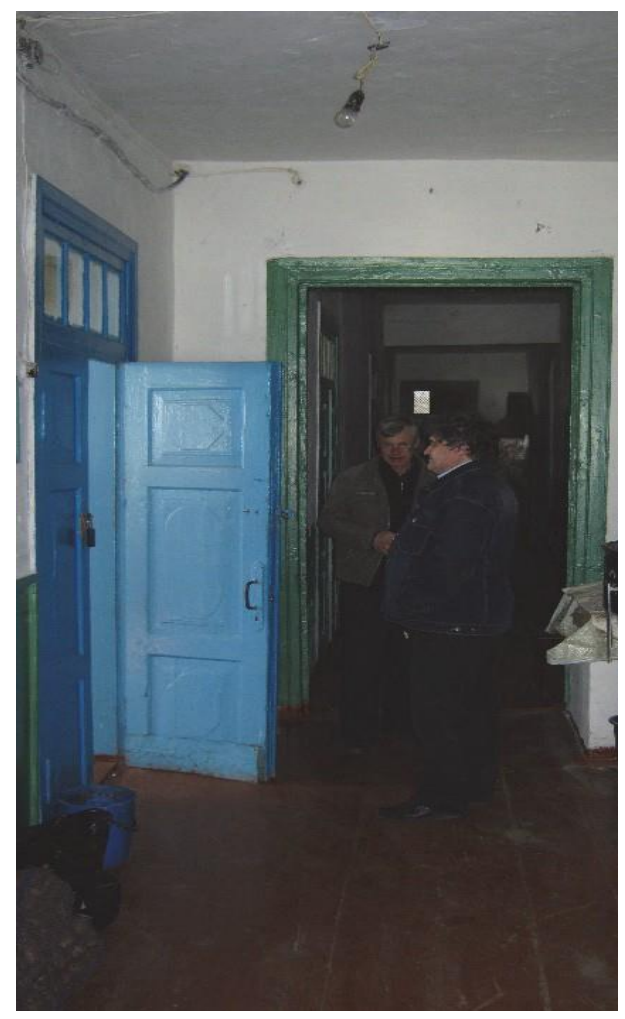

Коридор маєтку Чайковських в Бірках (фото 2011 р.) 


\section{Джерела та література:} 1971.

1. Chudzikowska Jadwiga Dziwne życie Sadyka Paszy o Michale Czajkowskim. Warzsawa,

2. Gazeta Lwowska. № 179. 8 серпня 1911 p.

3. Rawita-Gawronski Fr. Michal Czaykowski (Sadyk-pasza). Jego zycie, dzialalnosc wojskowa i literacka. Zarys biograficzny. Petersburg, 1901.

4. Державний архів Чернігівської області (далі- ДАЧО). Ф. 679. Оп. 10. О.з. 2501. Арк. 276.

5. ДАЧО. Ф. 679. оп. 10. О.зб. 2492. Арк. 324 зв. - 325.

6. Книга записи смертей находящихся на излечении в военном госпитале г.Симферополь (1919-1920), арк. 21. URL: https://forum.vgd.ru/4248/110337/ (дата звернення: 01. 11. 2021).

7. Полторак В. М. Адам Чайковський у чотирикутнику Париж - Стамбул - Петербург Варшава. Чорноморська минувшина. Вип. 8. 2013. С. 59-69.

8. Полторак В. М. Владислав Чайковський (Музаффер-паша) - від козака до губернатора Лівану. Східний світ. 2019. №4(105).

9. Рибак М. Михайло Чайковський - Мегмет Садик Паша. Альманах украӥнського національного союзу. Нью-Йорк, 1971. С. 86 - 97.

10. Стойчев И. К. Казак-алаят на Чайковски. София, 1943.

\section{Referenses:}

1. Chudzikowska Jadwiga Dziwne życie Sadyka Paszy o Michale Czajkowskim. PIW, 1971. [in Polish].

2. Gazeta Lwowska. № 179. 8 серпня 1911 p. [in Polish]

3. Rawita-Gawronski, Fr. (1901) Michal Czaykowski (Sadyk-pasza). Jego zycie, dzialalnosc wojskowa i literacka. Zarys biograficzny. Petersburg. [in Polish]

4. Derzhavnyy arkhiv Chernihivs'koyi oblasti (dali - DACHO). F. 679. Op. 10. O.Z. 2501. Ark.276. [in Russian].

5. DACHO. F. 679. op. 10. O.Zb. 2492. Ark. 324 zv. - 325. [in Russian].

6. Kniga zapisi smertey nakhodyashchikhsya na izlechenii v voennom gospitale g.Simferopol (1919-1920), ark. 21. Available at: < https://forum.vgd.ru/4248/110337/> [Accessed 01 November 2021]. [in Russian].

7.Poltorak, V. M. (2013) Adam Chaykovs'kyy u chotyrykutnyku Paryzh - Stambul - Peterburh - Varshava. Chornomors'ka mynuvtshyna, vol. 8, pp. 59-69. [in Ukranian].

8. Poltorak, V. M. (2019) Vladyslav Chaykovs'kyy (Muzaffer-pasha) - vid kozaka do hubernatora Livanu. Skhidnyy svit, №4 (105), pp. 103-112. [in Ukranian].

9. Rybak, M. (1971) Mykhaylo Chaykovs'kyy - Mehmet Sadyk Pasha. Al'manakh ukrayins'koyi natsional'noyi spilky. N'yu-York, pp. 86-97. [in Ukranian].

10. Stoychev, I. K. (1943) Kozak-alayat na Chaykovs'komu. Sofiya. [in Bolgarian]. 